\title{
O VOLUME 75 DA REVISTA DE AGRICULTURA
}

\section{Frederico Pimentel Gomes}

Começou sua vida a Revista de Agricultura em novembro-dezembro de 1926, sob a direção do Prof. Nicolau Athanassof (Director). Apareciam como Redactores o Prof. Octavio Domingues e o Prof. Salvador de Toledo Piza Júnior. Eram todos três, nessa ocasião, professores da "Escola Agrícola Luiz de Queiroz", hoje Escola Superior de Agricultura Luiz de Queiroz, da Universidade de São Paulo.

Ao começar a Segunda Grande Guerra, em 1939, publicava a Revista seu Volume 14. Constaram na capa, como Directores, além dos três fundadores mencionados, também os Professores Carlos Teixeira Mendes e Philippe Westin Cabral de Vasconcellos. O primeiro artigo desse volume, era Erosão do $\mathrm{Eng}^{\circ} \mathrm{Agr}^{\circ}$ Fernando Penteado Cardoso, que, posteriormente, chefe da Manah S.A. colaborou financeiramente com a Revista por muitos anos, através da publicação de anúncio permanente na sua quarta capa. Com 574 páginas de texto, esse foi um dos maiores volumes da Revista já publicados. Ele inclui longo artigo, de 108 páginas. $A$ Murcha do Algodoeiro, do Eng $^{\circ}$ Agr $^{\circ}$ A.P. Viégas, do Instituto Agronômico de Campinas, com nada menos de 595 referências bibliográficas.

O fundador principal da Revista de Agricultura, Nicolau Athanassof, faleceu em três de agosto de 1955. Mas já em dois de junho de 1950 desaparecera o Prof. Carlos Teixeira Mendes, Diretor da Revista desde 1929. Athanassof, búlgaro de nascimento e diplomado em Genibloux (Bélgica), dirigiu a Revista, com dedicação extraordinária, desde o início, em 1926, até a sua morte em 1955. No ano seguinte passa o Prof. Salvador de Toledo Piza Júnior a ser Diretor Responsável, já no número 1 do volume 31, ano de 1956. Logo abaixo, figuram como Diretores Octavio Domingues e Philippe Westin Cabral de Vasconcelos, e surge, como Secretário, o Dr. Luiz Gonzaga Engelberg Lordello. Este quarteto se mante- 
ve na direção da Revista até 1967, mas, já no começo de 1968 (volume 43, numero 1) foi acrescido de mais um Diretor (F. Pimentel Gomes) e é eliminado o nome de um dos fundadores: Octavio Domingues. Domingues, há muitos anos transferido da Escola Luiz de Queiroz para a Universidade Federal Rural do Rio de Janeiro, nesta alcançara a aposentadoria, em 1967.

Nova modificação importante na direção da Revista ocorreu em 21 de janeiro de 1988, com o falecimento de Salvador de Toledo Piza Júnior. Já no volume 63, ano de 1988, restaram na chefia da Revista, como Diretores, Frederico Pimentel Gomes e Luiz Gonzaga Engelberg Lordello, completados por um Conselho Editorial de três membros: Professores Evoneo Berti Filho, Hilton T. Zarate do Couto e Marli de Bem Gomes.

Atualmente, conta a Revista com seis Diretores e Conselho Editorial de 23 membros, dos quais 21 são brasileiros e dois, argentinos. E a sua indexação se estende por 18 revistas especializadas, e mais o US Department of Agriculture, o Ministério de Agricultura dos Estados Unidos. É, sem dúvida, uma grande conquista, para um periódico científico que sempre trabalhou com recursos financeiros escassos. Só foi possível graças à colaboração de cientistas brasileiros, argentinos e uruguaios, que, como autores ou editores, jamais pouparam seus esforços. 